\title{
Forage and Cattle Responses to Different Grazing Intensities on Southern Pine Ridge
}

\section{H. A. PEARSON AND L. B. WHITAKER}

Highlight: Over a 10-year span, grazing intensities of 35, 49, and $57 \%$ use of the current year's growth did not affect total forage yields on southern pine range. However, yields started to decline when the young pines were about age 9. Calf crops were highest from cows grazing lightly and lowest with heavy stocking; calf weaning weights and daily gains did not differ because of stocking rates. Highest total returns per calf were received from cows grazing lightly. Greatest returns per acre were from herds grazing heavily.

Southern pine forests provide substantial quantities of forage after timber harvest and until reforestation appreciably shades out the understory plants. Grazing varies from heavy to light, but livestock responses to grazing intensities have not been well defined. This research assesses effects of grazing regimes on the production efficiency of beef breeding herds. Findings pertain to some eight million acres comprising the western portion of the longleaf-slash pine type, where bluestem grasses predominate in the understory.

\section{Study Methods}

\section{Area}

The three-unit, 1,600-acre, study area is on the Palustris Experimental Forest in central Louisiana. Annual precipitation averages 58 inches. Soils are mainly deep, medium-textured, and slowly permeable; but some are coarse-textured and permeable. Topography varies from poorly drained flats to rolling hills with slopes up to $10 \%$.

The longleaf pine forest had been cut prior to 1935, and when the study began only scattered pines and oaks were present. Slender blucstem (Andropogon tener (Nees) Kunth) and pinehill bluestem ( $A$. divergens (Hack.) Anderss. ex Hitchc.) were the dominant herbaceous species. Other prominent species were fineleaf bluestem ( $A$. subtenuis Nash), paintbrush bluestem ( $A$. ternarius Michx.), Elliott bluestem (A. elliottii Chapm.), big bluestem ( $A$. gerardii Vitm.), and several panicums (Panicum spp.). Carpetgrass (Axonopus affinis Chase) occurs on heavily grazed areas. The main shrub is southern waxmyrtle (Myrica cerifera $\mathrm{L}$.)

In 1961 and each of the next 3 years, $25 \%$ of the area was regenerated to slash pines ( $P$. elliottii Engelm. var. elliottii). About $17 \%$ of each unit was planted with 1 -year-old seedlings (908 per acre), and $8 \%$ was direct-seeded with $1 \mathrm{lb}$ per acre. Prescribed burning prepared the land for pine regeneration and drew cattle away from the newly regenerated land. Prescribed burning resumed on regenerated areas when trees were age 5 or older. The effects of grazing on pine regeneration were reported in detail by Pearson et al. (1971). In brief, heavy grazing caused loss of about $18 \%$ of the planted pines; however, more than 550 well-distributed trees survived at age 5. Seeded stands under all grazing regimes and planted stands under light and moderate grazing were not affected.

Authors are principal range scientist and range technician, Southern Forest Experiment Station, U.S. Department of Agriculture, Forest Service, Pineville, Louisiana.

Manuscript received February 25, 1974.

\section{Cattle Management}

Cows were typical crossbred native piney-woods cattle. The majority showed evidence of Brahman breeding while the remainder were mixtures of other beef and dairy breeds. Purebred bulls (Hereford or Shorthorn) were mated with the native cow herds for December through March calving; calves were weaned and marketed in mid-August when about 210 days old.

Cattle diets were supplemented mainly for protein and mineral deficiencies (Duvall and Whitaker, 1963; Duvall and Hansard, 1967; and Pearson and Whitaker, 1972). About 400 pounds of cottonseed cake were hand-fed each animal from November through May; salt and steamed bonemeal were provided free-choice year round. Grass hay, fed during periods of inclement winter weather, averaged $260 \mathrm{lb}$ per animal year.

\section{Grazing Treatments}

In the summer of 1960 , three yearlong treatments of grazing intensity were randomly applied to contiguous range units, two of 580 acres each and one of 440 acres. Stocking rates calculated to atain light, moderate, and heavy grazing were 26, 20, and 13 acres per animal. These rates were projected to give intensities of about 30,45 , and $60 \%$ utilization of the current year's available forage.

Between May 1960 and May 1963, one-quarter of each range unit was rotationally prescribe-burned each year. Cattle prefer to graze areas most recently burned, since forage quality is improved (Duvall and Whitaker, 1964). The number of acres of burned range per cow-year remained relatively constant throughout the study, with greatest acreages under light stocking and least under heavy stocking.

\section{Measurements}

Forage production and utilization were determined from clusters of four plots, each $9.6 \mathrm{ft}^{2}$ in area. One plot in each cluster was caged and its yield was taken as a measure of forage production. The other three plots were grazed plots, and their mean yield was subtracted from that of the caged plot to calculate forage utilization. Between 35 and 40 clusters of plots were systematically distributed over the grazing units and were relocated annually.

\section{Analyses}

Since grazing treatments were unreplicated, results of this study are not suitable for statistical analysis. Standard deviations of forage yield means were computed within years. Regression analyses of yearly forage yield means give some indications of the overstory-understory relationships following pine regeneration. Calf responses under the various grazing regimes were evaluated by covariance analysis ${ }^{1}$ with age of calf and dam as covariates.

\section{Results and Discussion}

\section{Herbage}

Herbage yields varied greatly among years. In 1961-62

${ }^{1}$ Analyses were conducted by Dr. J. W. Turner, Department of Animal Science, Louisiana State University, Baton Rouge, presently at the Department of Animal Science, Mississippi State University, State College. 
Table 1. Herbage production (lb/acre) by years under three grazing intensities.

\begin{tabular}{cccr}
\hline \hline & \multicolumn{3}{c}{ Grazing intensity } \\
\cline { 2 - 4 } Year & Light & Moderate & Heavy \\
\hline $1961-62$ & 2154 & 2033 & 2732 \\
1963 & 2006 & 1841 & 2356 \\
1964 & 1696 & 1819 & 2320 \\
1965 & 1609 & 1918 & 2201 \\
1966 & 1804 & 1932 & 2203 \\
1967 & 1701 & 2024 & 2028 \\
1968 & 2068 & 2388 & 1979 \\
1969 & 2015 & 2382 & 2536 \\
1970 & 1518 & 1840 & 1597 \\
1971 & 1284 & 1232 & 1310 \\
1972 & 1093 & 815 & 860 \\
Average & 1723 & 1839 & 2011 \\
\hline
\end{tabular}

production averaged from 2,000 to $2,700 \mathrm{lb} /$ acre in the three range units (Table 1), with standard deviation for pasture yields averaging $600 \mathrm{lb}$. Yields on all units were above 1,600 lb until the 1969-70 growing season, but declined to $1,300 \mathrm{lb}$ during 1970-71 and 900 during 1971-72. Apparently, the timber stand did not appreciably decrease the yields until trees were about 9 years of age. Regression analysis of yearly means indicates reductions in herbage production after tree age 8 (Fig. 1). A definite decline was noted under the oldest stand of pine-age 9-with light and heavy grazing (Fig. 2). At tree age 11 , herbage yields were 496, 744, and $356 \mathrm{lb} /$ acre under the light, moderate, and heavy grazing intensities. Areas with younger trees partially compensated these low herbage productions in the older stands; consequently, cattle numbers were not reduced during the first 10 years following regeneration. However, cattle numbers were decreased about $10 \%$ on all pastures during the 11 th year.

Herbage responses were probably related to both site and growing treatment (Table 1). Heavy grazing initially had the highest yields; however, a slight downward trend was noted until 1968. Yields with moderate grazing were initially lowest but demonstrated a slight upward trend after 1963. Yields with light grazing declined through 1964 then trended upward. These increases with light and moderate grazing were partially due to hardwood control during 1963-64. However, herbage yields-possibly influenced by grazing intensity-were greater with moderate grazing after 1963 than with light grazing. Duvall and Linnartz (1967) reported that grazing stimulates yields on pine-bluestem range.

Botanical composition changed somewhat with grazing; for instance, pinehill bluestem decreased with heavy grazing while carpetgrass increased (Pearson and Whitaker, 1974).

Years since prescribed burning did not affect the 10-year average herbage yields (Table 2). Possibly without burning, the pine needle cast would have reduced the production sooner. However, nonburned comparisons were not available.

Stocking levels provided 10-year forage utilization of 35 , 49 , and $57 \%$ on the light, moderate, and heavy grazing intensities (Table 2). Yearly fluctuations of forage utilization under light intensity ranged from 29 to $41 \%$; moderate 41 to 57; and heavy 47 to 65 . Total yields apparently were not affected since production remained unchanged until tree competition reduced yields.

Burned range received higher utilization than unburned (Table 2). During 1963 when burning had occurred only 3 years, similar utilization results on the lightly grazed unit

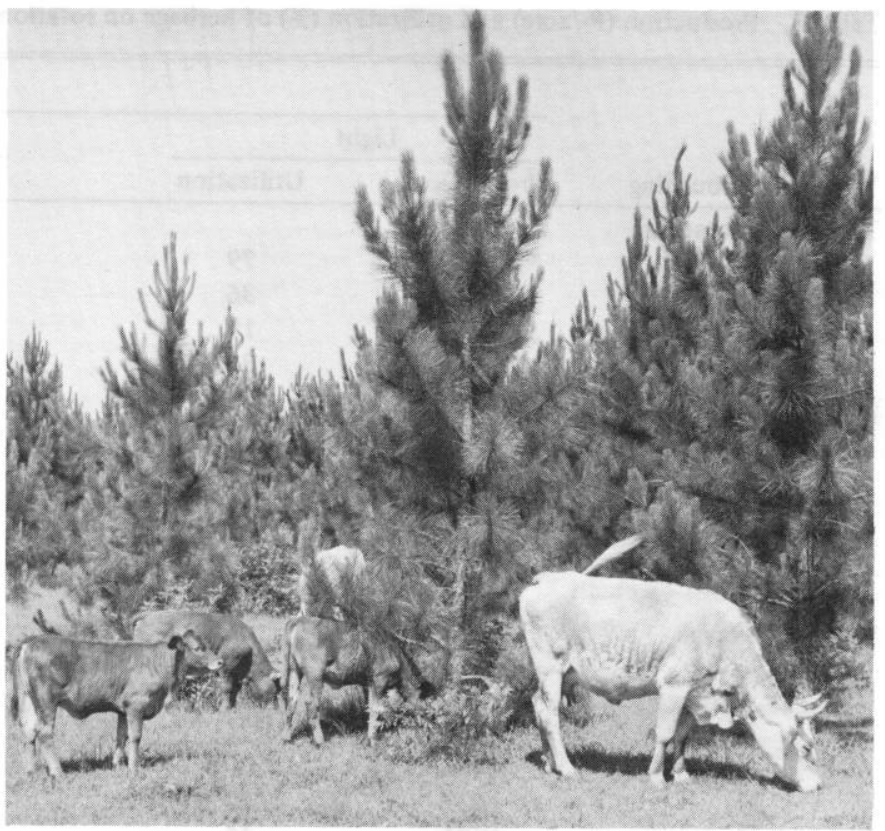

Fig. 1. Cattle grazing among pines 7 years of age.

occurred as previously reported (Duvall and Whitaker, 1964). Utilization increased with grazing intensity. Consequently, utilization of the 3 -year rough was 34 and $42 \%$ on moderate and heavy intensities and 19\% on light intensity.

Herbage production with light stocking also responded as previously reported (Duvall and Whitaker, 1964). Yields were lower on first-year rough than on 3-year roughs. Moderate and heavy grazing reacted differently, but reasons are not apparent from these data.

Utilization was again examined after the fourth burn. These results differed from those reported by Duvall and Whitaker (1964) and the 3-year burn results in this study. Utilization was higher on the burned portion but was highly variable thereafter. When utilization with years since burning was averaged, it did not change between the second and fifth year (Table 2). Apparently cattle prefer the newly burned forage but are not highly selective when a variety of forages with different burning ages are in the pasture.

\section{Cattle}

Fluctuations in cow weight, calf crops, and calf weaning weights are indicative of the nutritional status of the range and feeding program. Random selection and potential productivity of the cow herds were assumed to be the same for all grazing

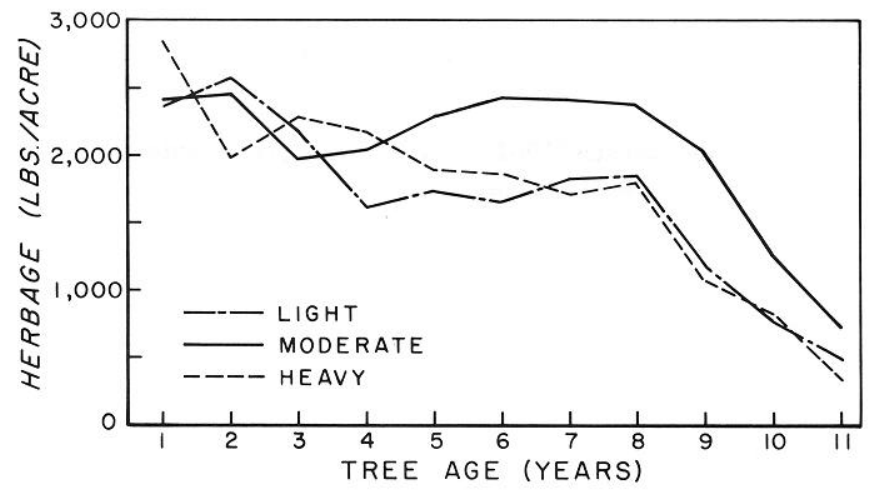

Fig. 2. Herbage production under 1961 regenerated pines and three grazing intensities. 
Table 2. Production (lb/acre) and utilization (\%) of herbage on rotation-burned range.

\begin{tabular}{|c|c|c|c|c|c|c|}
\hline \multirow[b]{3}{*}{ Years ${ }^{1}$ since burning } & \multicolumn{6}{|c|}{ Grazing intensity } \\
\hline & \multicolumn{2}{|c|}{ Light } & \multicolumn{2}{|c|}{ Moderate } & \multicolumn{2}{|c|}{ Heavy } \\
\hline & Production & Utilization & Production & Utilization & Production & Utilization \\
\hline \multicolumn{7}{|l|}{ Three-year rotation ${ }^{2}$} \\
\hline 1 & 1289 & 79 & 1771 & 87 & 2469 & 93 \\
\hline 2 & 1955 & 36 & 1163 & 41 & 2488 & 50 \\
\hline 3 & 2575 & 19 & 2477 & 34 & 1977 & 42 \\
\hline Average & 2006 & 32 & 1841 & 46 & 2356 & 57 \\
\hline \multicolumn{7}{|l|}{ Four-year rotation } \\
\hline 1 & 1174 & 51 & 2080 & 72 & 2041 & 88 \\
\hline 2 & 1280 & 41 & 1593 & 40 & 2155 & 56 \\
\hline 3 & 2031 & 29 & 1591 & 27 & 2585 & 40 \\
\hline 4 & 2184 & 40 & 1979 & 29 & 2361 & 57 \\
\hline Average & 1696 & 38 & 1819 & 41 & 2320 & 56 \\
\hline \multicolumn{7}{|l|}{ Ten-year average } \\
\hline 1 & 1566 & 68 & 2052 & 78 & 2120 & 81 \\
\hline 2 & 1640 & 31 & 1546 & 49 & 2090 & 60 \\
\hline 3 & 1762 & 26 & 1945 & 43 & 1982 & 48 \\
\hline 4 & 1605 & 30 & 1777 & 40 & 2040 & 55 \\
\hline 5 & 1627 & 27 & 1689 & 33 & 1894 & 55 \\
\hline 6 & 1901 & 16 & 2158 & 38 & 2213 & 42 \\
\hline Average & 1786 & 35 & 1941 & 49 & 2126 & 57 \\
\hline
\end{tabular}

${ }^{1}$ Data apply to herbage produced after burning.

${ }^{2}$ One-fourth of each range unit rotation burned annually.

intensities. Although cows on lightly grazed pastures were heaviest, cow weights did not differ appreciably among grazing intensities (Table 3).

Cows grazing lightly had the highest annual percent calf crop weaned, while those grazing heavily had the lowest. Average percent calf crops were 82,73 , and 70 for the light, moderate, and heavy intensities. Calf crops varied from 65 to 95\% for light stocking; 61 to 89 for moderate; and 58 to 79 for heavy.

Calves from light grazing were slightly heavier at weaning than from the other two grazing treatments. Steers $(441 \mathrm{lb})$ weaned heavier than heifers $(418 \mathrm{lb})$. Daily weight gains from April through weaning in August were similar for all grazing intensities-about 1.74 pounds.

Brahman breeding in cows apparently affected weaning weights of calves. Cows with none, one-quarter, one-half, and three-quarters Brahman had calf weaning weights of 416,421 , 436, and $444 \mathrm{lb}$. Calves from cows with one-half and threequarters Brahman breeding weaned heavier than calves from cows with no Brahman, regardless of grazing intensity.

The selling price per pound was essentially identical on calves sold at weaning; however, returns per calf differedhighest returns were received from the lightly grazed pasture (Table 3). The calf market price varied between $\$ 16$ and $\$ 35$ per hundred pounds during the 10 years. Steers brought better

Table 3. Cattle statistics (1961-71) under three grazing intensities.

\begin{tabular}{lrcr}
\hline & \multicolumn{3}{c}{ Grazing intensity } \\
\cline { 2 - 4 } & Light & Moderate & Heavy \\
\hline Cow weights (lb) & 819 & 778 & 788 \\
Calf crop (\%) & 82 & 73 & 70 \\
Calf weaning weight (lb) & 444 & 419 & 421 \\
Calf sale weight (lb) & 427 & 403 & 404 \\
Price/cwt (\$) & 25.60 & 25.27 & 25.51 \\
Returns/calf (\$) & 108.96 & 102.15 & 103.14 \\
Returns/cow (\$) & 89.35 & 74.57 & 72.20 \\
Returns/acre (\$) & 3.44 & 3.73 & 5.55 \\
\hline
\end{tabular}

prices and returns than heifers. Calves with highest amounts of Brahman breeding had greatest returns (\$108.94), attributable to heavier weaning weight. Southern forest grazing showed greatest returns per cow $(\$ 89.35)$ from herds grazing lightly and greatest returns per acre $(\$ 5.55)$ from herds grazing heavily.

Current prices greatly enhance returns. Using the $\$ 42$ per hundred weight received in 1972 , returns would be $\$ 147.06$ per cow with light grazing and $\$ 9.14$ per acre with heavy grazing. Economic implications regarding costs and returns with the various grazing regimes were reported by Pearson and Whitaker (1973).

Returns from cattle grazing will decline as the tree crowns close and forage yields diminish. Some increase will occur when the trees are thinned, perhaps at ages 15 to 18 years. When commercial harvest commences, economic considerations will involve integrated management for timber and livestock.

\section{Literature Cited}

Duvall, V. L., and S. L. Hansard. 1967. Responses of southern range cattle to protein supplementation. J. Range Manage. 20:153-157.

Duvall, V. L., and N. E. Linnartz. 1967. Influences of grazing and fire on vegetation and soil of longleaf pine-bluestem range. J. Range Manage. 20:241-247.

Duvall, V. L., and L. B. Whitaker. 1963. Supplemental feeding increases beef production on bluestem-longleaf pine ranges. La. Agr. Exp. Sta. Bull. 564. 18 p.

Duvall, V. L., and L. B. Whitaker. 1964. Rotation burning: a forage management system for longleaf pine-bluestem ranges. J. Range Manage. 17:322-326.

Pearson, H. A., L. B. Whitaker, and V. L. Duvall. 1971. Slash pine regeneration under regulated grazing. J. Forest 69:744-746.

Pearson, H. A., and L. B. Whitaker. 1972. Thrice-weekly supplementation adequate for cows on pine-bluestem range. J. Range Manage. 25:315-316.

Pearson, H. A., and L. B. Whitaker. 1973. Returns from southern forest grazing. J. Range Manage. 26:85-87.

Pearson, H. A., and L. B. Whitaker. 1974. Yearlong grazing of slash pine ranges: effects on herbage and browse. J. Range Manage 27:195-198. 